\title{
Peritoneal carcinomatosis: the importance of laparoscopy
}

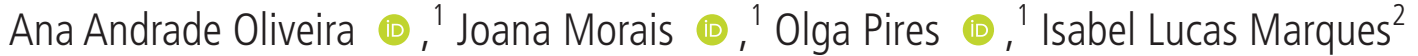

${ }^{1}$ Internal Medicine, Hospital de Braga, Braga, Portugal ${ }^{2}$ General Surgery, Hospital de Braga, Braga, Portugal

\section{Correspondence to} Dr Ana Andrade Oliveira; anaandradeoliveira100@gmail. com

Accepted 17 September 2021

\section{DESCRIPTION}

A 64-year-old woman presented with diffuse abdominal pain, postprandial bloating and $5 \mathrm{~kg}$ of unintentional weight loss in the last 3 months. She had a previous medical history of nephrectomy due to recurrent pyelonephritis and hypothyroidism. Physical examination revealed only mild tenderness in the umbilical area. Relevant laboratory values included a normocytic normochromic anaemia $(11.7 \mathrm{~g} / \mathrm{dL})$ and positive CA-125 (100.9 U/mL). CT presented areas of irregular soft tissue thickening of the peritoneum, multiple peritoneal nodules and mild ascites; uterus and adnexa had no abnormalities. Transvaginal ultrasound confirmed a homogeneous and normal-sized uterus and morphologic large ovaries, without expansive lesions. Positron emission tomography confirmed diffuse heterogeneous peritoneal ${ }^{18} \mathrm{~F}-\mathrm{FDG}$ uptake, consistent with carcinomatosis, and enlarged lymph nodes with ${ }^{18} \mathrm{~F}-\mathrm{FDG}$ uptake in the supraclavicular, hilar, oesophageal, paratracheal, preaortic and external iliac lymph nodes. Peritoneal fluid revealed 56\% of lymphocytes and high activity of ascitic fluid adenosine deaminase (ADA) (63 UI/L). Interferon gamma release assay (IGRA) to detect Mycobacterium tuberculosis infection was positive ( $>10 \mathrm{UI} /$ $\mathrm{mL}$ ). The remaining examinations performedupper gastrointestinal endoscopy, colonoscopy, breast ultrasound, mammography-were normal.

Exploratory laparoscopy unmasked a peritoneum with a strawberry appearance (figure 1), with multiple white nodules/granulomas. The histopathological examination of parietal peritoneum biopsies and round ligament samples revealed a necrotising granulomatous inflammation involving the peritoneum (granulomatous peritonitis), suggestive of Mycobacterium, with no evidence of neoplasia. Ziehl-Neelsen test for acid-fast bacilli was negative; cultures were not performed.

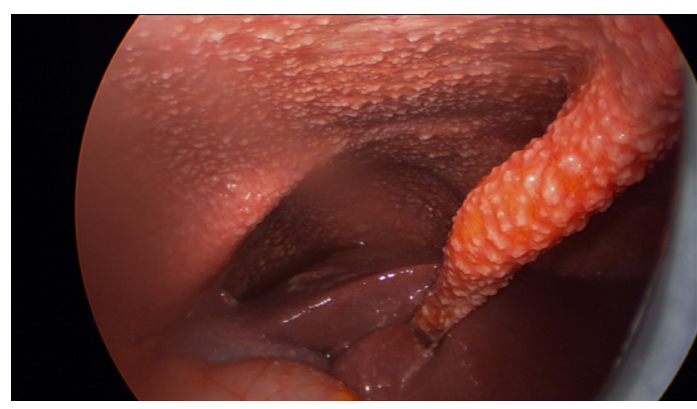

Figure 1 Laparoscopy image of peritoneal tuberculosis, revealing a peritoneum with a strawberry appearance, with multiple white nodules/granulomas on its surface.

\section{Learning points}

- Abdominal tuberculosis should be considered in patients who present non-specific abdominal reports, peritoneal thickening of unknown origin in the abdominal CT and increased CA-125 levels.

- Laparoscopy is reported as the ideal method for early diagnosis because of the magnified observation of the peritoneal surfaces.

After exclusion of malignancy, the diagnosis of peritoneal tuberculosis was made and antituberculosis agents were initiated (ethambutol, rifampicin, isoniazid and pyrazinamide) and maintained for 9 months, with complete resolution of the radiological alterations. There were no signs of relapse after 2 years of follow-up.

Peritoneal tuberculosis involves the parietal and visceral peritoneum and intestinal mesentery; it can be provoked by a reactivation of a latent tuberculous infection of the peritoneum, rupture of caseous abdominal lymph nodes or haematogenous spread of the infection. ${ }^{12}$ This disease is often difficult to distinguish from peritoneal carcinomatosis due to its non-specific symptoms and similar radiological presentation. ${ }^{3}$ Peritoneal tuberculosis should be considered in any patient presenting with ascites, peritoneal thickening and increased levels of CA-125. ${ }^{4}$ Laparoscopy is reported as the ideal method for early diagnosis because it allows a magnified observation of the peritoneal surfaces; any surgeon should be aware of the typical laparoscopic findings enabling an early diagnosis. ${ }^{56}$ The histological confirmation of the granulomatous involvement and high activity of ADA are also extremely useful for the diagnosis since a negative culture cannot exclude tuberculosis. ${ }^{57}$

Contributors AAO conducted the research, collected the data, designed the paper and wrote the article. JM collected the data and revised the final paper. OP collected the data and reviewed the final paper. ILM performed the laparoscopy, collected data and reviewed the final paper.

Funding The authors have not declared a specific grant for this research from any funding agency in the public, commercial or not-for-profit sectors.

Competing interests None declared.

Patient consent for publication Consent obtained directly from patient(s)

Provenance and peer review Not commissioned; externally peer reviewed. 


\section{ORCID iDs}

Ana Andrade Oliveira http://orcid.org/0000-0002-8603-8020

Joana Morais http://orcid.org/0000-0002-6588-9010

Olga Pires http://orcid.org/0000-0003-0618-9820

\section{REFERENCES}

1 Arvind S, Raje S, Rao G, et al. Laparoscopic diagnosis of peritoneal tuberculosis. J Minim Invasive Gynecol 2019;26:346-7.

2 Tortorelli AP, Rosa F, Papa V, et al. Peritoneal tuberculosis. Surgery 2012;151:488-9.
3 Lata Verma M, Tripathi V, Singh U, et al. Peritoneal tuberculosis with benign ovarian tumor. Indian J Tuberc 2019;66:499-501.

4 Ospina-Moreno C, González-Gambau J, Montejo-Gañán I, et al. Peritoneal tuberculosis. radiographic diagnosis. Rev Esp Enferm Dig 2014;106:548-51.

5 Terras Alexandre A, Raimundo S, Pinto C. Peritoneal tuberculosis - a rare diagnosis. Pulmonology 2017:23:172-3

6 Clancy C, Bokhari Y, Neary PM, et al. Diagnosing peritoneal tuberculosis. Case Rep Child Meml Hosp Chic 2013;19:bcr2013009871.

7 Bulut Gökten D, Katipoglu B, Basara E, et al. A case report of peritoneal tuberculosis: a challenging diagnosis. Case Rep Infect Dis 2018;2018:4970836

Copyright 2021 BMJ Publishing Group. All rights reserved. For permission to reuse any of this content visit

https://www.bmj.com/company/products-services/rights-and-licensing/permissions/

BMJ Case Report Fellows may re-use this article for personal use and teaching without any further permission.

Become a Fellow of BMJ Case Reports today and you can:

- Submit as many cases as you like

- Enjoy fast sympathetic peer review and rapid publication of accepted articles

- Access all the published articles

- Re-use any of the published material for personal use and teaching without further permission

\section{Customer Service}

If you have any further queries about your subscription, please contact our customer services team on +44 (0) 2071111105 or via email at support@bmj.com.

Visit casereports.bmj.com for more articles like this and to become a Fellow 